Ann. Biol. anim. Bioch. Biophys., I976, 16 (3), 433-44I.

\title{
EFFECTS OF ELECTRICAL STIMULATION AND OF DIRECT CURRENT AND HIGH FREQUENCY LESIONS OF THE HYPOTHALAMUS ON GONADOTROPHIN RELEASE AND PUBERTY IN FEMALE RATS
}

J. MOLL, Henriette M. A. MFIJS-ROELOFS, P. KRAMER and J. DULLAART

\author{
Department of Anatomy, Medical Faculty, \\ Erasmus University, \\ Rotterdam (The Netherlands)
}

\begin{abstract}
SUMMARY
The arcuate nucleus region of the hypothalamus of twenty-eight day old female rats was subjected to either electrical stimulation (AC), direct current (DC) lesions, high frequency (HF) lesions or to sham-procedures. Gonadotrophin levels were measured at various times after treatment. At 0-3o mn after treatment a significant rise in LH level was seen in AC, DC and HF rats, which rise was significantly higher in $\mathrm{DC}$ and $\mathrm{HF}$ rats than in $\mathrm{AC}$ rats. At 3 hours after treatment no differences in LH levels were found between the various groups; FSH levels tended to be higher in stimulated and lesioned rats, but this reached significance for HF rats only. At 2 days after treatment $\mathbf{L H}$ as well as FSH levels were not different in experimental and control groups with the exception of lower FSH levels in the AC group. AC rats uniformly showed advancement of vaginal opening (VO), accompanied by (first) ovulation ; occurrence of these phenomena was much more variable in DC and HF rats. Measurements of gonadotrophin levels at $\mathrm{I} 7.00 \mathrm{~h}$ on the day preceding the day of VO demonstrated peak levels of both L.H and FSH in all control and $\mathrm{AC}$ rats. For DC and HF rats high levels of LH and FSH were encountered in those animals that had ovulated on the day of VO.

It is concluded that in the immature rat hypothalamic lesions are effective via stimulation of gonadotrophin release. Advanced first ovulation in lesioned and stimulated rats is preceded by gonadotrophin surges comparable to those at spontaneous first ovulation, while, at least under experimental conditions, VO may occur without ovulatory gonadotrophin release and ovulation.
\end{abstract}

\section{INTRODUCTION}

In immature rats interference with brain function by means of either direct current (DC) lesions, high frequency (HF) lesions or purely electrical stimulation with alternating current $(\mathrm{AC})$ of the hypothalamus may advance vaginal opening (VO) and first ovulation (DONOVAN and VAN DER WERFF TEN BOSCH, I959; 
SchiAvi, I964; MeIJs-Roelofs and MolL, I972; MeIJs-Roeitofs, I972). Little is known about the hormonal chain of events which to all probability connects intervention in brain function with advancement of vaginal opening and first ovulation. This may (at least in part) explain the discrepancies in interpretation of results obtained in lesion studies : stimulation vs removal of inhibition as modus operandi of lesions? (see e.g. Sherwood and TIMIras, I974; RUF, YounglaI and Hormes, I974).

In the adult rat an acute stimulatory effect on gonadotrophin release of DC lesions (in most cases referred to as electrochemical stimulation) is well-known (see e.g. BISHOP et al., I972; CLEMENs et al., I97I ; KALRA et al., I971). An acute increase in ovarian oestrogen and progestin content after DC lesions in immature rats has been reported (RUF, Younglar and HolmES, 1974). In personal studies we found a marginal elevation of FSH levels and a clear increase in LH levels within 3 hours after AC stimulation of the hypothalamus (MEIJS-ROELOFS and UIIENBROEK, I973).

The present work deals with changes in gonadotrophin levels at various times after both $\mathrm{DC}$ lesions, $\mathrm{HF}$ lesions and $\mathrm{AC}$ stimulation. It was hoped that comparison of these three methods of manipulation of brain function might provide a better insight in their mode of action and usefulness in research on puberty. Of particular interest seemed the question whether lesions act via removal of inhibition or by stimulation of hypothalamic drive of pituitary-ovarian function.

\section{MATERIAL AND METHODS}

Female rats of the R-Amsterdam strain, a Wistar substrain, were used. They were weaned at 22 days of age and kept in a controlled temperature of $22-25^{\circ} \mathrm{C}$ with lights on from $05.00-19.00 \mathrm{~h}$. They received standard dry pellets and tap water ad libitum. At 28 days of age litter-mates were divided over the various experimental and control groups; body weights were 48-60 g at this age. Rats were subjected to either alternating current (AC) stimulation, direct current (DC) lesions, high frequency (HF) lesions or to sham procedures. Blood samples were taken at various times after operation for determination of serum gonadotrophin concentrations. All rats were weighed and checked for vaginal opening (VO) daily. From the day of VO vaginal smears were taken during at least 20 days ; animals were killed at the vaginal metoestrous stage that followed the first day of oestrus after 20 days of smearing. If vaginal cyclicity was irregular or absent, rats were killed zo days after VO. In one separate experiment blood samples were taken on the day preceding the expected day of $\mathrm{VO}$ as judged by the appearance of the vaginal area (see MEIJs-Roelofs et al., in press). In this experiment rats were killed at first metoestrus or on the day following that of VO, if a metoestrous smear was not then found. Some intact rats were bled at 33 days of age to provide an additional control group.

Brains and ovaries of operated rats were prepared for histological study of stimulation and lesion sites and for determination of presence or absence of corpora lutea.

Blood for gonadotrophin determination was obtained under light ether anaesthesia by puncture of the ophthalmic venous plexus and was allowed to clot overnight in a refrigerator before centrifugation. Serum samples were stored at $-20^{\circ} \mathrm{C}$. Serum luteinizing hormone (LH) and follicle stimulating hormone (FSH) concentrations were estimated by radioimmunoassay as described earlier (WeLschen et al., 1975).

Stimulation and lesion procedures were performed stereotaxically under ether anaesthesia. Electrodes were inserted bilaterally $0.5 \mathrm{~mm}$ from the midsagittal plane and aimed at the region of the arcuate nucleus, using the stereotaxic atlas of the developing rat brain of SHERwood and TIMIRAs (I97.0). For AC stimulation bipolar stainless steel electrodes (Rhodes Medical Instruments, California, model SNE-IOo) with an outer diameter of $0.25 \mathrm{~mm}$ were used. A current of $\pm 35^{\circ} \mu \mathrm{A}$ peak-to-peak, consisting of trains of biphasic rectangular pulses with on/off periods of ıo sec, was passed during $60 \mathrm{mn}$, using a Grass S-8 stimulator (for further details see MeIJS-Roelofs, I972). 
For DC and HF lesions, unipolar stainless steel electrodes $(\varnothing 0.2 \mathrm{~mm}$; uninsulated tip $0.5 \mathrm{~mm}$ ) were employed. DC lesions were made with a continuous direct current of $1.5 \mathrm{~mA}$ during Io $\sec (15 \mathrm{mC})$; a Grass constant current unit connected with a Grass S-8 stimulator was used. For $\mathrm{HF}$ lesions a radio frequency current was passed during zo sec. Long-term and short-term sham procedures were performed : electrodes were inserted during $60 \mathrm{mn}$ or a few seconds respectively and no current was passed. Since no differences were seen for any of the parameters studied, data from both types of sham-operated controls have been combined. Only rats in which lesions included (parts of) the arcuate nucleus were used. The various groups with $\mathrm{HF}$ and DC lesions and the individual rats in these groups differed in advancement of VO. Slight differences in the position of the lesions seemed to be related to these differences in time of VO. Lesions reaching the posterior border of the optic chiasm and causing definite damage of the median eminence appeared to be more effective in advancing VO than lesions with a slightly more posterior and slightly more dorsal position. Following DC and HF lesions anovulation occurred with varying frequency; no association between anovulation and position of the lesions could be found in in the present animal material.

In some cases groups of rats were subdivided on the basis of presence or absence of advanced VO. Criteria were as described previously (MEIJs-RosLoFs, 1972) and involved comparison with litter-mates as well as with the pooled controls : age and body weight at VO should be lower than in all intact litter-mates and at least 3 days and/or $15 \mathrm{~g}$ less than those of the pooled controls for acceptance of advancement. Mean age and body weight at VO in the pooled intact and sham-operated controls were $38.3 \pm 0.3$ days and $92.5 \pm 1.3 \mathrm{~g}(n=33)$.

Without treatment, day of VO and day of first ovulation nearly always coincide in our rats (Meijs-Roelofs, I972).

The statistical analysis of the results was carried out using Wilcoxon's two sample test. A difference was considered as significant, if the double tail probability was $\leqslant 0.05$. Values were expressed as mean \pm SEM.

\section{RESUL'TS}

A. - In the first group of rats the effects of $\mathrm{AC}$ stimulation and of HF and DC lesions of the region of the arcuate nucleus on acute $\mathrm{LH}$ release as well as on the occurrence of VO and cyclicity were studied. Blood was taken immediately after the 60 min period of stimulation in the $\mathrm{AC}$ rats ; 30 minutes after treatment in the $\mathrm{DC}$ and $\mathrm{HF}$ rats and at comparable times in the respective control groups. Results are given in table I A and figure $\mathrm{r}$. A uniform and clear effect on VO was obtained in the AC rats : all rats showed an advancement of $\mathrm{VO}$ to 32 or 33 days of age with a mean body weight of $6 \mathrm{r} .3 \mathrm{~g}$. In the $\mathrm{DC}$ and $\mathrm{HF}$ group advancement of VO was less pronounced and less uniform : only half of the $\mathrm{DC}$ rats and $\mathrm{I} / 4$ of the HF rats showed advancement of VO; moreover cyclicity as judged by the presence of corpora lutea (table I) was clearly disturbed in these two groups, whereas $\geqslant 2$ generations of corpora lutea were always present in $\mathrm{AC}$ rats. In the cyclic animals of all three groups the first cycle tended to be prolonged and often had a pseudopregnancy-like length.

All three treatment groups showed a significant rise in $\mathrm{LH}$ concentration as compared to the controls. Moreover, LH levels were significantly higher in HF and $\mathrm{DC}$ rats than in the $\mathrm{AC}$ group.

B. - The second group of $\mathrm{AC}, \mathrm{DC}$ and $\mathrm{HF}$ rats and their controls were bled 3 hours after treatment as well as 2 days after treatment, at $15.00 \mathrm{~h}$. Results are given in table I B and figure $I$.

Again all $\mathrm{AC}$ rats showed advanced $\mathrm{VO}$ in contrast to the $\mathrm{HF}$ and $\mathrm{DC}$ rats ; the percentages of $\mathrm{DC}$ and $\mathrm{HF}$ rats with advanced VO were somewhat higher than in group A. Cyclicity, as judged by presence of $\geqslant 2$ generations of corpora lutea was less disturbed in this experiment. 
At three hours after treatment $\mathrm{LH}$ levels did not differ between the various experimental and control groups. FSH levels at three hours after operation tended to be somewhat higher in the stimulated and lesioned animals, but this was of (borderline) significance in the HF group only.

TABLE I

Effects of $A C$ stimulation and of $D C$ and $H F$ lesions of the arcuate nucleus region on vaginal opening and subsequent cycles

\begin{tabular}{|c|c|c|c|c|c|}
\hline \multirow{2}{*}{$\begin{array}{l}\text { Experimental } \\
\text { group }\end{array}$} & \multirow{2}{*}{$\begin{array}{l}\text { Effect } \\
\text { on VO }\end{array}$} & \multirow{2}{*}{$\mathrm{N}^{\circ}$ of rats } & \multicolumn{2}{|c|}{ Vaginal opening at } & \multirow{2}{*}{$\begin{array}{l}N^{\circ} \text { of rats with } \\
\geqslant 2 \text { generations } \\
\text { of corpora lutea }\left({ }^{1}\right)\end{array}$} \\
\hline & & & Age (days) & Bodyweight (g) & \\
\hline $\mathrm{AC}$ & + & 7 & $32.4 \pm 0.2$ & $61.3 \doteq 1.7$ & $7 / 7$ \\
\hline $\mathrm{DC}$ & + & $\begin{array}{l}4 \\
4\end{array}$ & $\begin{array}{l}33.5 \pm 0.3 \\
41.3 \pm 0.5\end{array}$ & $\begin{array}{r}71.9 \pm 4.9 \\
100.8 \pm 2.7\end{array}$ & $\begin{array}{l}3 / t^{\prime} \\
1 / 4\end{array}$ \\
\hline $\mathrm{HF}$ & + & 2 & $\begin{array}{l}33.0 \pm 0.0 \\
38.5 \pm 1.0\end{array}$ & $\begin{array}{l}62.8 \pm 0.3 \\
92.0 \pm 6.3\end{array}$ & $\begin{array}{l}0 / 2 \\
1 / 6\end{array}$ \\
\hline Sham & - & 9 & $39.0 \pm 0.9$ & $95.5 \pm 4.0$ & $9 / 9$ \\
\hline Intact & - & 7 & $37.6 \pm 0.3$ & $91.4 \pm 1.4$ & \\
\hline$A C$ & + & 7 & $32.4 \pm 0.2$ & $64.5 \pm 0.6$ & $7 / 7$ \\
\hline$D C$ & + & $\begin{array}{l}6 \\
4\end{array}$ & $\begin{array}{l}33.8 \pm 0.5 \\
39.5 \pm 0.7\end{array}$ & $\begin{array}{l}63.8=1.6 \\
86.0=3.6\end{array}$ & $\begin{array}{l}5 / 6 \\
3 / 4\end{array}$ \\
\hline $\mathrm{HF}$ & + & $\begin{array}{l}4 \\
6\end{array}$ & $\begin{array}{l}33.5 \pm 0.3 \\
40.7 \pm 0.8\end{array}$ & $\begin{array}{l}66.0 \pm 1.5 \\
90.8 \pm 2.6\end{array}$ & $\begin{array}{l}2 / 4 \\
4 / 6\end{array}$ \\
\hline Sham & - & 8 & $40.0 \pm 0.7$ & $90.6 \pm 2.4$ & $8 / 8$ \\
\hline Intact & - & 7 & $38.5 \pm 0.6$ & $95.9 \pm 2.9$ & \\
\hline
\end{tabular}

(1) 20-30 days after VO.

Two days after treatment $\mathrm{LH}$ levels were generally low and no differences were found between any of the experimental and control groups. The same holds for the FSH levels, with the exception of the AC group where FSH tended to be lower than in the other groups of lesioned as well as control animals. The data are shown in figure I.

C. - In this group of rats blood was taken from $\mathrm{AC}, \mathrm{DC}$ and $\mathrm{HF}$ rats and from untreated rats at $\mathbf{I 7 . 0 0 ~} \mathrm{h}$ on the day preceding the expected day of VO. Effects of the various treatments on day of VO and on first ovulation are presented in table 2 ; LH and FSH levels are shown in figure 2.

A uniform advancement of $\mathrm{VO}$ and first ovulation was again found in all $\mathrm{AC}$ rats. In this experiment an advancement of VO, slightly smaller than that in the $\mathrm{AC}$ rats, was found in the majority of the DC and HF rats, but in about half of the $\mathrm{DC}$ and $\mathrm{HF}$ rats VO was not accompanied by first ovulation. 

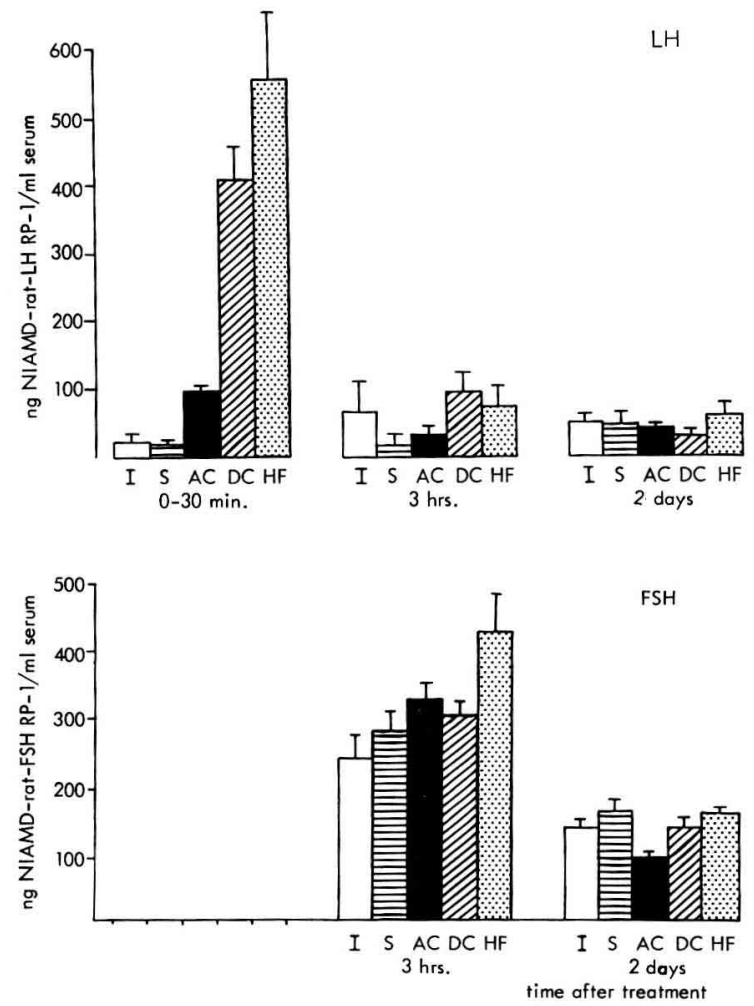

FIG. I. - Serum LH and FSH concentrations at various times after a direct current (DC) or a high frequency (HF) lesion or after electrical stimulation (AC) of the region of the arcuate nucleus. Data on intact (I) or sham-stimulated (S) rats included. Values are given as mean \pm SEM, each group consisted of 7-ro rats.

TABLE, 2

Effects of $A C$ stimulation and of $D C$ and $H F$ lesions of the arcuate nucleus region on vaginal opening and first ovulation

\begin{tabular}{|c|c|c|c|c|c|c|}
\hline \multirow{2}{*}{$\begin{array}{l}\text { Experimental } \\
\text { group }\end{array}$} & \multirow{2}{*}{$\begin{array}{l}\text { Effect } \\
\text { of treat- } \\
\text { ment }\left({ }^{1}\right)\end{array}$} & \multirow{2}{*}{ No of rats } & \multicolumn{2}{|c|}{ Vaginal opening at } & \multirow{2}{*}{$\begin{array}{l}\text { Ovulation } \\
\text { in... rats }\end{array}$} & \multirow{2}{*}{$\begin{array}{c}\text { No of corpora } \\
\text { lutea }\end{array}$} \\
\hline & & & Age (days) & Bodyweight (g) & & \\
\hline $\mathrm{AC}$ & + & 9 & $32.3 \pm 0.2$ & $59.1 \pm 0.9$ & $9 / 9$ & $8.8 \pm 0.4$ \\
\hline $\mathrm{DC}$ & + & $\begin{array}{r}12 \\
1\end{array}$ & $\begin{array}{l}32.2 \pm 0.2 \\
39\end{array}$ & $\begin{array}{l}58.9 \pm 1.7 \\
95\end{array}$ & $6 / 13$ & $8.9 \pm 0.4$ \\
\hline $\mathrm{HF}$ & + & $\begin{array}{r}11 \\
2\end{array}$ & $\begin{array}{l}33.9 \pm 0.1 \\
36.5 \pm 0.5\end{array}$ & $\begin{array}{l}65.0 \pm 1.8 \\
80.0 \pm \mathbf{2 . 0}\end{array}$ & $5 / 13$ & $8.5 \pm 0.3$ \\
\hline Intact & - & 8 & $38.5 \pm 0.7$ & $88.4 \pm 2.4$ & $8 / 8$ & $10.0 \pm 0.4$ \\
\hline
\end{tabular}

(') + : advanced vaginal opening. - : no effect. 
High ovulatory concentrations of both $\mathrm{LH}$ and FSH were found in all untreated rats (I $350 \pm 105 \mathrm{ng} / \mathrm{ml}$ and $\mathrm{I}$ IOI $\pm 66 \mathrm{ng} / \mathrm{ml}$ respectively) as well as in all $\mathrm{AC}$ treated rats (I $020 \pm \mathrm{I} 26$ vs. $588 \pm 60 \mathrm{ng} / \mathrm{ml}$ ). In the $\mathrm{DC}$ group high $\mathrm{LH}$ and FSH levels were encountered in the rats that had ovulated on the day of VO

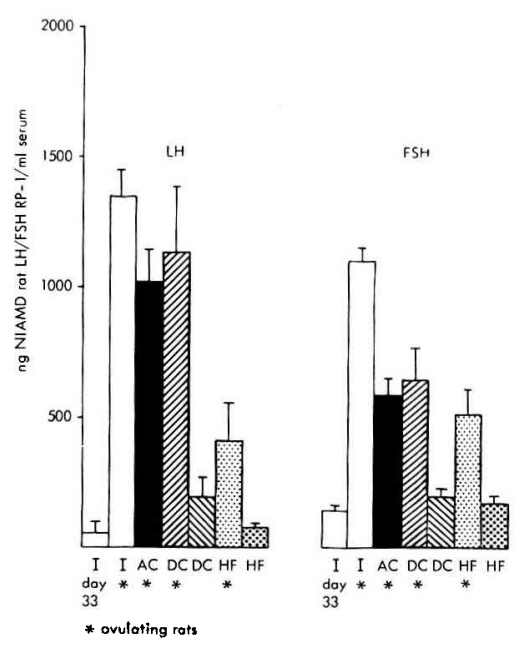

FIg. 2. - Serum $L H$ and $F S H$ concentrations at $17.00 h$ on the day preceding the day of vaginal opening in intact rats (I) after electrical stimulation (AC) after a direct current (DC) lesion or after a high frequency (IIF) lesion of the region of the arcuate nucleus. Intact rats bled at 33 days of age served as additional controls. Values are given as mean \pm SEM, each group consisted of 5-8 rats.

(I I38 \pm 240 vs $639 \pm 137 \mathrm{ng} / \mathrm{ml}$ ), while low values were found in rats where VO was not accompanied by (first) ovulation. In $\mathrm{HF}$ rats also, elevated $\mathrm{L}_{4} \mathrm{H}$ and FSH levels were found in rats that had ovulated one day later (4IO \pm I46 vs. $5 \mathrm{II} \pm 99 \mathrm{ng} / \mathrm{ml}$ ) and low levels in the non-ovulating rats. In contrast to the findings in all other groups of ovulating animals $L H$ values in ovulating $H F$ rats were lower than the FSH values. The LH levels of the HF rats showed, although to a minimal degree only, overlap of gonadotrophin levels of ovulating and non-ovulating rats.

Ovarian histology showed normal numbers of corpora lutea in all ovulating rats, although numbers tended to be slightly higher in the untreated controls. Partially luteinized follicles or corpora lutea with an entrapped ovum were occasionally found among the $\mathrm{AC}, \mathrm{DC}$ and $\mathrm{HF}$ rats, but also in a single control rat. In non-ovulating $\mathrm{DC}$ and $\mathrm{HF}$ rats large atretic follicles and/or thin-walled follicular cysts were the dominating elements in the ovaries.

\section{DISCUSSION}

The reported observations show that both direct current (DC) and high frequency (HF) lesions as well as purely electrical (AC) stimulation of the area of the arcuate nucleus cause an acute increase of gonadotrophin secretion, at least of LH. This 
effect was least pronounced after AC stimulation. Two days after treatment gonadotrophin levels of treated and control animals could generally not be distinguished, with the exception of AC animals that tended to have lower FSH levels.

Clearly, the acute increase in $\mathrm{LH}$ level, observed in all treated animals, was not uniformly related to advancement of vaginal opening (VO) and first ovulation. Gonadotrophin levels two days after treatment did not predict advancement of VO and/or ovulation either, an observation that seems to be in agreement with that reported by RAMIREZ (I974).

However, the highly constant occurrence of advanced VO and advanced first ovulation in $\mathrm{AC}$ rats, showing a modest, acute rise in $\mathrm{LH}$ and low FSH levels two days later, suggest a relationship between gonadotrophin levels and VO and ovulation at least in this group. Another difference between $\mathrm{AC}$ rats on the one hand and $\mathrm{DC}$ and $\mathrm{HF}$ rats on the other, is the lesser damage to brain structures that may be essential for both negative and positive feedback effects and, therefore, for processes leading to vaginal opening and first ovulation. The greater brain damage in DC and $\mathrm{HF}$ rats, possibly interfering to a variable degree with feedback mechanisms, might account for the more irregular advancement of VO in these animals as well as for the frequent occurrence of VO not associated with ovulation and subsequent cycles.

It seems likely that the acute increase in gonadotrophin level, presumably caused by an increase in gonadotrophin releasing factor secretion induced by a lesion or by stimulation, causes a rise in ovarian steroid production as observed by RUF et al. (I974) in rats with $\mathrm{DC}$ lesions. This may first lead to inhibition of gonadotrophin secretion (e.g. low FSH levels as observed in $\mathrm{AC}$ rats) and subsequently to ovulatory gonadotrophin release by positive feedback, provided negative and positive feedback centers are intact. A similar chain of events seems to occur in male induced puberty in the mouse (BRonson and DESJARDINS, I974). Advancement of first ovulation was indeed always associated with a preceding surge of gonadotrophin secretion, comparable to that at spontaneous first ovulation in control rats (see also MEIJS-ROELOFS et al., I975). In non-ovulating rats no gonadotrophin surge was seen on the day before VO, emphasizing that experimentally induced advanced VO does not necessarily imply advanced onset of cycling. Advanced VO not associated with a gonadotrophin surge may be brought about by an oestrogen secretion that is inadequate to elicit a positive feedback effect (a) or can not elicit a positive feedback because of damage to essential brain structures $(b)$. Possibility $(b)$ may be the case in our lesioned rats that remained a-cyclic till at least 30 days after VO.

An unusual phenomenon was the higher ovulatory elevation of FSH than of $\mathrm{LH}$ as observed in $\mathrm{HF}$ rats only. A quantitatively disturbed regulation of gonadotrophin secretion, caused by hypothalamic damage, may be the explanation.

The observed hormonal effects of interference with brain function can all be adequately described as stimulatory effects. No evidence was obtained that lesions eliminate inhibitory influences on gonadotrophin release as has often been suggested (see e.g. CRITCHLOW and BAR-SELA, I967). The similarity between the effects of lesions and of electrical stimulation is a further argument for considering the lesions as stimulatory. It is surprising that also HF lesions result in immediate gonadotrophin release and thus act stimulatory in immature rats, whereas $\mathrm{HF}$ 
lesions do not induce ovulation in adult rats (EVERETT, I964). The more caudal position of the lesions in our immature rats may partly explain this discrepancy.

The present observations finally suggest that interference with brain function stimulates the hypothalamo-hypophysial-ovarian axis at a different site, but otherwise in a comparable way as treatments like administration of gonadotrophins or oestrogens, which may also induce advancement of VO and first ovulation. It seems essential that one of the elements of the hypothalamo-hypophysial-ovarian system is activated; it does not seem to be essential which element is activated primarily. Therefore, it can in our opinion not be deduced from such experiments that either the brain, the hypophysis or the ovaries have a dominant role in sexual maturation.

The more constant results regarding VO, ovulation and cycles obtained with the $\mathrm{AC}$ stimulation technique indicates that $\mathrm{AC}$ stimulation is a better tool for further exploration of the role of the brain in sexual maturation than the lesion technique. The observation that $\mathrm{AC}$ stimulation is without influence on sexual maturation at an age where lesions are effective (compare HOROWITZ and VAN DER WERFF TEN BosCh, I962 and Meijs-RoELOFS, I972) may at least in part be due to the stronger acute stimulation of gonadotrophin release caused by lesions.

Sexual Maturation, 3 vd Workshop
August 31, September 3,1975.

\author{
RÉSUMÉ \\ EFFET DE STIMULATIONS ÉLECTRIQUES ET DE LÉSIONS ÉLECTRIQUES \\ OU ÉLECTROLYTIQUES DE L'HYPOTALAMUS SUR LA LIBÉRATION \\ DES GONADOTROPINES ET LA PUBERTÉ CHEZ IA RATTE
}

\begin{abstract}
Des rattes âgées de 28 jours ont été soumises à une lésion à courant à haute fréquence (HF), ou à une lésion électrolytique (courant continu, DC), ou à une stimulation électrique (courant alternatif et pulsatif, AC) ou à une opération-fantôme dans l'hypothalamus basal au niveau du noyau arqué. Le dosage des hormones gonadotropes sériques à divers moments après le traitetement montre une augmentation immédiate (0-30 $\mathrm{mn}$ après l'opération) du niveau de $\mathrm{LH}$ dans les groupes $\mathrm{AC}, \mathrm{DC}$ et $\mathrm{HF}$. Cette augmentation est plus forte dans les groupes DC et HF que dans le groupe AC. Après 3 heures, les niveaux de LH sont comparables dans tous les groupes, tandis que les niveaux de FSH tendent à être plus élevés chez les animaux stimulés ou lésés, mais ce n'est significatif que dans le groupe HF. Deux jours après l'opération les niveaux en LH et FSH sont comparables dans les groupes traités ou témoins, à l'exception du groupe AC où la concentration en FSH est plus faible. L'ouverture vaginale (VO) ainsi que la première ovulation sont accélérées chez toutes les rattes $\mathrm{AC}$, les résultats sont plus variables pour les rattes DC et HF. A I 7 h oo la veille de l'ouverture vaginale, la LH et la FSH présentent des pics (d'un niveau préovulatoire) chez les rattes témoins et $\mathrm{AC}$. Chez les rattes DC et HF les concentrations de LH et FSH sont élevées chez celles où l'ovulation se produit le jour de l'ouverture vaginale.

Cette étude met en évidence que chez la Ratte immature une lésion hypothalamique a une action stimulante sur la sécrétion des hormones gonadotropes (I), que l'ovulation précoce est précédée d'une décharge de gonadotropines comme la première ovulation spontanée (2) et que l'ouverture vaginale dans des conditions expérimentales peut se produire sans décharge de gonadotropines et sans ovulation.
\end{abstract}




\section{REFERENCES}

Bishop W., Fawcett C. P., Krulich L., McCann S. M., I972. Acute and chronic effects of hypothalamic lesions on the release of $\mathrm{FSH}, \mathrm{LH}$ and prolactin in intact and castrated rats. Endocrinology, 91, $643-656$

Bronson F. H., Desjardins C., I974. Circulating concentrations of FSH, LH, estradiol and progesterone associated with acute, male-induced puberty in female mice. Endocrinology, 94, 1658-1668.

Clemens J. A., ShaAr J., Kleber J. W., Tandy W. A., I97r. Areas of the brain stimulatory to $\mathrm{LH}$ and FSH secretion, Endocrinology, 88, I80-I84.

Critchlow V., Bar-Sela M. E., r967. Control of the onset of puberty, roi-r62, in : Martini L., Ganong W. F., Neuroendocrinology, 2, New York London : Academic Press.

Donovan B. T., Van der Werff ten Bosch J. J., 1959. The hypothalamus and sexual maturation in the rat. J. Physiol., 147, 78-92.

Everets J. W., I964. Preoptic stimulative lesions and ovulation in the rat : "Thresholds" and LHrelease time in late diestrus and proestrus, 346-366, in : BAJUSZ E., JASMIN G., Major problems in neuroendocrinology, Basel/New York, Karger, S.

Horowitz S., VAN DER WerfF TEN Bosch J. J., I962. Hypothalamic sexual precocity in female rats operated shortly after birth. Acta endocr., 41, 30I-3I3.

Kalra S. P., Ajika K., Krulich L., Fawcett C. P., Quijada M., McCanN S. MI., I97I. Effects of hypothalamic and preoptic electrochemical stimulation on gonadotrophin and prolactin release in proestrous rats. Endocrinology, 88, I I 50-I 158 .

Meijs-Roelofs H. M. A., 1972. Effect of electrical stimulation of the hypothalamus on gonadotrophin release and the onset of puberty. J. Endocr., 54, 277-284.

Meijs-Roelofs H. M. A., Moll J., I972. Differential effects of anterior and middle hypothalamic lesions on vaginal opening and cyclicity. Neuroendocrinology, 9, 297-303.

Meijs-Roelofs H. M. A., Uilenbroek J. Th. J., I973. Gonadotrophin release and follicular development after electrical stimulation of the hypothalamus in the immature female rat, $117+123$, in : Peters $11 .$, The development and maturation of the ovary and its functions. Excerpta Medica Foundation, ICS 267 , Amsterdam.

Meijs-Roelofs H. M. A., Uilenbroek J. Th. J., De Greef W. J., De Jong F. H., Kramer P., 1975. Gonadotrophin and steroid levels around the time of first ovulation in the rat. $J$. Endocr., 67, 275-282.

Ramirez V. D., I974. Discussion, 209, in : Grumbach M. M., Grave G. D., Maler F. E., The Control of the onset of puberty, John Wiley and Sons, New York.

RuF K. B., Younglad E. V., Holmes M. J., I974. Induction of precocious sexual maturation in female rats by electrochemical stimulation of the brain. Brain Research, 78, 437-446.

Schiavi R. C., r964. Effect of anterior and posterior hypothalamic lesions on precocious sexual maturation. Am. J. Physiol., 206, 805-810.

Sherwood N. M., Timiras P. S., r970. A stereotaxic atlas of the developing rat brain. University of California Press, Berkeley, California.

Sherwood N. M., Timiras P. S., I974. Comparison of direct-current and radio-frequency-current lesions in the rostral hypothalamus with respect to sexual maturation in the female rat. Endocrinology, 94, $1275-1285$.

Welschen R., Osman P., Dullaart J., De Greef W. J., Uilenbroek J. Th. J., De Jong F. H., I975. Levels of follicle stimulating hormone, oestradiol-i $7 \beta$ and progesterone and follicular growth in the pseudopregnant rat. J. Endocr., 64, 37-47. 